IZA DP No. 6647

Impact of Industrialization on Relative Female Survival: Evidence from Trade Policies

Tanika Chakraborty

June 2012 


\title{
Impact of Industrialization on Relative Female Survival: Evidence from Trade Policies
}

\author{
Tanika Chakraborty \\ Indian Institute of Technology, Kanpur \\ and IZA
}

Discussion Paper No. 6647

June 2012

IZA

P.O. Box 7240

53072 Bonn

Germany

Phone: +49-228-3894-0

Fax: +49-228-3894-180

E-mail: iza@iza.org

\begin{abstract}
Any opinions expressed here are those of the author(s) and not those of IZA. Research published in this series may include views on policy, but the institute itself takes no institutional policy positions.

The Institute for the Study of Labor (IZA) in Bonn is a local and virtual international research center and a place of communication between science, politics and business. IZA is an independent nonprofit organization supported by Deutsche Post Foundation. The center is associated with the University of Bonn and offers a stimulating research environment through its international network, workshops and conferences, data service, project support, research visits and doctoral program. IZA engages in (i) original and internationally competitive research in all fields of labor economics, (ii) development of policy concepts, and (iii) dissemination of research results and concepts to the interested public.
\end{abstract}

IZA Discussion Papers often represent preliminary work and are circulated to encourage discussion. Citation of such a paper should account for its provisional character. A revised version may be available directly from the author. 


\section{ABSTRACT}

\section{Impact of Industrialization on Relative Female Survival: Evidence from Trade Policies}

This paper exploits an exogenous shift in the trade policy in India to study the impact of industrialization on son preference. Using a difference-in-differences strategy, we find that households are more likely to have a male child in regions with higher trade openness relative to regions with lower trade openness. Moreover, higher trade openness seems to have affected only the Hindu households; there is no analogous effect on the Muslim households. We further analyze the underlying mechanisms through which industrialization might have affected relative survival of daughters. We find a significant increase in real dowry payments in regions experiencing greater trade openness. Most interestingly, dowry inflation is experienced by the Hindu households, but not by the Muslim households. The results are robust to falsification tests using cohorts born much before the liberalization period and are not driven by systematic migration into areas with greater trade openness.

JEL Classification: J16, J18, J71, O15

Keywords: sex ratio, dowry, trade liberalization, difference in difference

Corresponding author:

Tanika Chakraborty

Department of HSS-Economics

Indian Institute of Technology

Kanpur, UP 208016

India

E-mail: tanika@iitk.ac.in

\footnotetext{
* I am grateful to Sukkoo Kim, Sebastian Galiani and Robert Pollak for their advice and guidance, and to Karen Norberg and Edward Greenberg for their helpful comments and suggestions. I also want to thank the seminar participants at the Berlin Network of Labor market Research (BeNA), DIW Berlin (2009), European Society of Population Economics 2010,World Congress of the Econometric Society 2010 and EEA 2010 meetings. I am grateful to NCAER and Andrew Foster for providing me access to the REDS data. I also want to thank Siddharth Sharma for sharing his data on district mappings across years in India. All errors are mine.
} 


\section{Introduction}

The imbalance in sex ratio characterizing the population of many Asian countries has caused a number of authors to argue that there is substantial excess female mortality in Asia (Sen 1990; Coale 1991; Klasen 1994). In general, they argue that neglect of female children and poor conditions for women contribute to the abysmally low proportion of females in the population.

Previous theoretical and empirical economic insights on gender imbalance focus on household level economic incentives affecting imbalance in sex ratios. Some of these are income (Becker 1991, Rose 1999), differential earning opportunities for women (Bardhan, 1974; Rosenzweig and Schultz, 1985, Duflo 2002, Qian 2005) and relative status of women within different kinship systems(Dyson and Moore 1993, \& Chakraborty and Kim 2008). There are also studies that put forth biological factors, to explain sex ratio imbalance (Norberg 2004; Oster 2005) ${ }^{1}$

However, the previous literature has paid less attention to the importance of economy wide changes that might in turn affect household choices. Recent sex ratio statistics show a consistent decline in the proportion of females in many Asian countries, particularly over the past few decades. Contrary to what common sense would dictate, over the same period these economies also had rapid industrialization enabling them to come out of the traditional agricultural sector. China and India, in particular, have experienced high growth rates driven mainly by the non-agricultural sector and at the same time the concern for relatively fewer females in the population has intensified. From a public policy standpoint it is important to understand whether these counter intuitive associations are causal since it would imply that the relative scarcity of women will keep growing in the decades to come with current predictions of persistent economic growth. Few papers which do address the debate on the role of economic development in reducing gender discrimination are Foster and Rosenzweig 2001, Burgess and Zhuang 2001, Bhattacharya 2006 and Pande

\footnotetext{
${ }^{1}$ Norberg argues that cohabitation causes male bias. Oster claims that Hepatitis B explains about $20 \%$ of the sex ratio differential in India. However, both of these hypotheses affect sex ratio only at birth, they don't explain the differential mortality in early childhood
} 
and Astone 2007. Foster and Rosenzweig explore the agricultural growth in India following Green Revolution and geographical marriage market of women to underline the role of economy wide changes in shaping son preference. However, growth in agriculture says little about the impact of modernization on son preference. Bhattacharya finds that share of nonagricultural laborers or better infrastructure significantly reduced relative excess female mortality. ${ }^{2}$ Pande and Astone, 2007, on the contrary, find that village level economic development is not enough to change gender preferences. Thus, the existing evidence on the role of economic development in changing excess female mortality, based on aggregate data and cross section studies, is mixed. One important reason for the mixed results could be the endogeneity of industrialization and economic development with parental preference for sons. For instance, if non agricultural growth is driven by supply of educated labor and better educated households have systematically different preferences then estimates of the effect of industrial or economic development on relative female survival would be biased. In this paper, I address this endogeneity problem by using an exogenous policy shift in India, to analyze the impact of industrialization, at the time of the policy shift, on relative female survival.

This paper also contributes to the growing body of literature which analyzes the consequences of trade openness on various measures of development. While previous literature focuses mainly on the effects of trade on wage inequality, gender gap in wages and schooling and child labor outcomes, there is no previous attempt at understanding how trade openness affects household preferences for sons or daughters. In this paper I discuss how trade affected the relative survival chances of female children and the mechanism driving such changes.

Following the balance of Payments crisis of 1980s, India was forced to undergo a series of trade reforms in the 90s, starting with the slashing of tariff rates in July 1991. The average effective tariff rate was reduced from about 86 per cent in 1989-90 to about 40 per cent in 1994-95, and further to about 30 per cent in 1999-2000 (Goldar, 2002). I exploit the variation in the degree of trade

\footnotetext{
${ }^{2}$ Burgess and Zhuang, find qualitatively similar evidence from China's rural industrialization
} 
openness across districts to capture the effect of industrialization on son preference. Using tariff data from the World Integrated Trade System (WITS) I compute district level measures of the magnitude of tariff reduction in the industrial sector following the 1991 trade reforms. Then I link a household's probability of having a male child with the district level trade measures. The exposure of parents to the trade reform is determined both by the extent of tariff reduction in the district of their residence and by the cohort of birth of the concerned child. In other words, a child is exposed to the trade reform only if it is born close to or after the reform year of 1991. My estimation strategy is similar in spirit to a difference in difference strategy although it also estimates the effect on each birth cohort exposed to the reform. This reduces the probability that the results are confounded by the effect of other policies in the liberalization period. I find that households are more likely to have a male child in districts with higher trade liberalization as compared to their counterparts in the districts with relatively smaller changes in trade openness. My results are robust to falsification tests using cohorts born much before the liberalization period and hence not likely to be affected by preexisting differential district trends. They are also not driven by systematic migration into areas with greater trade openness.

At first glance it might appear that industrialization and development of an economy should lead to an improvement in the sex-ratio due to a positive change in all other socio- economic parameters that might affect son preference. Theoretically, however, industrialization might affect relative survival of girls through several channels. To the extent that poverty might drive households to allocate relatively fewer resources to the less valuable children, trade liberalization might lead to greater negligence of girls if poverty increases. Second, trade openness might affect relative preference for sons over daughters if the relative wage of women changes. Third, trade liberalization might affect relative marriage market value of females versus males by changing employment opportunities. For example, if trade leads to higher employment opportunities for men outside the traditional agricultural sector then marriage market value of men might increase. In a social setting 
characterized by marriage payments this will lead to a greater marriage price for men. ${ }^{3} \mathrm{I}$ find no significant evidence to suggest that household income or a change in female labor market opportunity is affecting relative female survival following trade liberalization. On the other hand, I find a significant increase in real dowry payments consequent upon trade liberalization. The practice of dowry as a marriage payment is traditionally prevalent amongst the Hindus and not Muslims. When I compare the 2 groups I find that trade openness has raised dowries only for Hindus. If dowry increases parental discrimination towards daughters then we would expect relative female survival to decline more for Hindus. Indeed, I find that trade liberalization affects relative survival of females only for Hindus. There is no comparable effect in the Muslim population.

The rest of the paper is organized as follows. Section 2 discusses the theoretical mechanisms by which industrialization might affect relative female survival. Section 3 describes the exogeneity of the trade reforms and its impact on industrialization. Section 4 outlines the empirical framework and estimation specifications. Section 5 summarizes the data sources. Sections 6 to 10 report and discuss the results and robustness checks. Section 11 concludes.

\section{Conceptual Framework}

Industrialization can affect relative survival of girls versus boys through a number of channels. First, it might change the relative status of women in the labor market by changing the returns to female labor in the industrial sector. Secondly, industrialization can also affect relative female survival through an income effect, by changing household income (Becker 1981). Third, industrialization, or in other words a movement away from the traditional occupational structure, might affect sex ratios by changing marriage payments for daughters. Anderson (2003) shows that in a socially segregated society, like India, industrialization leads to increasing dowry payments through increasing within-group wealth inequality due to a movement away from the traditional

\footnotetext{
${ }^{3}$ Anderson, 2003, provides a detailed theoretical framework explaining this mechanism
} 
occupation structure. In India, social status is determined not only by wealth but also by caste, a patrilineal inherited component of social status. Due to patrilineal inheritance if a girl marries down in the caste hierarchy, it leads to a loss in social status of her family. Anderson shows that in this framework, where marriages are arranged by the families of the bride and the groom, positive assortative matching implies that girls are matched with grooms of similar or higher status with respect to both caste and wealth. Modernization in such a framework leads to dowry-inflation due to increasing within caste inequality. To the extent that increase in dowry would reduce the desirability of girls, this might play an important role in determining relative expenditures on daughters in terms of health care or increasing the possibility of pre-natal sex selection. I develop a simple model to understand how industrialization might affect the relative neglect of daughters.

\subsection{Model}

We assume a 2 period utility maximization framework, where the head maximizes the single household utility function comprising of the current parental consumption (head and his spouse), a discounted future parental consumption, and a weighted component of the children's current consumption. The weights in the latter case are determined by an intrinsic preference for the gender of the child. Moreover, since we are interested in the allocation of resources between sons and daughters in their young age (i.e. in period 1 of this problem), we do not include future consumption of children in the household utility function. The utility function of the representative household can be written as

$$
c_{1}^{p} c_{2}^{\stackrel{M a x}{p} c_{1}^{F}} c_{1}^{M} U\left(c_{1}^{p}\right)+\beta U\left(c_{2}^{p}\right)+\gamma^{M} U\left(c_{1}^{M}\right)+\gamma^{F} U\left(c_{1}^{F}\right)
$$

where, $c_{1}^{i}$ is the period one consumption for household member i, $i \in$ Parent, Male Child, Female Child, $c_{2}^{p}$ is parental consumption in the second period. Consumption includes expenditure on health, education or pure food consumption. $s$ is savings of the household, $\gamma^{i}$ is the weight put 
on child i's consumption by the parents. The weight on parental consumption is assumed to be 1, i.e. $\gamma^{P}=1$. A caveat here is that the relative weight with which son's consumption enters the utility household function compared to the daughter's determines the existing preference over the gender of the child. $\gamma^{M}>\gamma^{F}$ would imply son preference. However, I do not assume an intrinsic son preference in this model. As we would see later, the predictions of the model (in terms of relative deprivation of female children) could simply follow from market forces and institutional norms even without pre-existing son preference.

The budget constraints of the household are comprised of the current and future flow of consumption and income. The pooled spousal income (we assume away any possibility of child labor) is allocated between: current parental consumption $c_{1}^{p}$, current consumption of sons $\left(c_{1}^{M}\right)$ and daughters $\left(c_{1}^{F}\right)$, and savings for use in period 2. In period 2, the household resources are composed of the savings carried over from period 1 and net transfers from sons and daughters. In period 2 the children participate in both the labor market as well as the marriage market. Hence the budget constraints are,

$$
\begin{array}{r}
c_{1}^{P}+s+c_{1}^{M}+c_{1}^{F}=A \\
c_{2}^{P}=s+\left[\alpha^{M} \tau^{M}\left(c_{1}^{M}\right)+\delta^{M}\left(c_{1}^{M}\right)\right]+\left[\alpha^{F} \tau^{F}\left(c_{1}^{F}\right)+\delta^{F}\left(c_{1}^{F}\right)\right] \\
0 \leq \tau^{M}, \tau^{F} \geq 1
\end{array}
$$

$\alpha^{i}$ is the return in the labor market for $i \in$ Male,Female. Total labor earnings would be a function of expenditure on health and education from in the first period. Thus, a healthier or more educated child would have a higher total return. For simplicity we assume that the market wage rate is given from outside and does not depend on these expenditures in the first period. Instead total earnings in the labor market depends on consumption in the first period through hours of work. Sons transfer a fraction $\tau^{M}$ of total earnings $\alpha^{M} c_{1}^{M}$ to parents. Similarly returns to female 
labor is $\alpha^{F}$ and they transfer $\tau^{F} \alpha^{M} c_{1}^{M}$ to the parents in period 2. Social institutions determine the size of $\tau^{i}$.

$\delta^{i}$ is the return in the marriage market, which would also depend on expenditures on children in the first period (for example more educated grooms could demand higher dowries). We assume that social norms determine the direction of cash flow in the marriage market. Particularly, we assume that marriage payments exist in the form of dowry, a transfer from boys' family to girls' family. ${ }^{45}$ Then we can think of $\delta^{M} c_{1}^{M}$ as the dowry paid to the son's family (a net transfer to the son's family). Hence $\left(\delta^{M}>0\right)$. On the other hand, since Dowry is to be paid by the parents of the daughter, $\delta^{F} c_{1}^{F}$ is a net tax on the daughter's family. Hence $\delta^{F}<0$. If we assume assortative matching, and that value of women in the marriage market is determined independent of the labor market, then the total amount of Dowry paid by the girl's family should also depend positively on $c_{1}^{F}$ since more educated daughters need to match with more educated grooms.

Each household solves the optimization problem in the first period to determine the optimal levels of $c_{1}^{P}, c_{1}^{F}, c_{1}^{M}$ and savings. For a logarithmic utility function and restricting our attention to interior solutions, the corresponding first order conditions are:

\footnotetext{
${ }^{4}$ A more general setting would be to allow for both Dowry and Brideprice, but since Dowry is the more prevalent phenomenon, we restrict our attention to Dowry for simplicity.

${ }^{5}$ Allowing for Brideprice and a decrease in price paid to the daughters family would mathematically be the same as an increase in Dowry paid by the daughter's family
} 


$$
\begin{aligned}
c_{1}^{p} & =\frac{1}{\lambda^{1}} \\
c_{1}^{F} & =\frac{\gamma^{F}}{\left[1-\alpha^{F} \tau^{F}-\delta^{F}\right]} \frac{1}{\lambda^{2}} \\
c_{1}^{M} & =\frac{\gamma^{M}}{\left[1-\alpha^{M} \tau^{M}-\delta^{M}\right]} \frac{1}{\lambda^{2}} \\
\lambda^{1}-\lambda^{2} & =0 \\
c_{1}^{P}+s+c_{1}^{M}+c_{1}^{F} & =A \\
c_{2}^{P} & =s+\left[\alpha^{M} \tau^{M}\left(c_{1}^{M}\right)+\delta^{M}\left(c_{1}^{M}\right)\right]+\left[\alpha^{F} \tau^{F}\left(c_{1}^{F}\right)+\delta^{F}\left(c_{1}^{F}\right)\right]
\end{aligned}
$$

These can be solved to obtain the equilibrium values of $c_{1}^{P}, c_{2}^{P}, c_{1}^{F}, c_{1}^{M}$ and $s$. However, here our focus is on comparative statics, i.e. how would relative expenditure on female children be affected in response to a change in the parameters, $\alpha, \tau$ and $\gamma$. Solving the FOCs in (2.1) we obtain

$$
\frac{c_{1}^{F}}{c_{1}^{M}}=\frac{\left[1-\alpha^{M} \tau^{M}-\delta^{M}\right]}{\left[1-\alpha^{F} \tau^{F}-\delta^{F}\right]} \frac{\gamma^{F}}{\gamma^{M}}
$$

Assuming a market clearing rate of dowry $\mathrm{D}$, such that total dowry paid/received is proportinate to consumption in the first period, and normalizing the male wage rate, $\alpha^{M}$ to one, the relative expenditure on daughters can be written as,

$$
c_{1}^{f}=\frac{\left[1-\tau^{M}-D\right]}{\left[1-\alpha^{f} \tau^{F}+D\right]} \frac{\gamma^{F}}{\gamma^{M}}
$$

Industrialization can affect the relative expenditure on (or deprivation of) sons and daughters, by changing the relative value of men or women in the labor market and/or the marriage market. I.e. relative expenditure, $\left(c_{1}^{f}\right)$, would depend on how $\alpha^{M}, \alpha^{F}$ or D change in response to industrialization 


\subsection{Dowry and relative expenditure on girls}

The expenditure on daughters relative to sons, respond to dowry in the following way:

$$
\frac{\delta c_{1}^{f}}{\delta D}=\frac{-\left[2-\tau^{M}-\alpha^{f} \tau^{F}\right]}{\left[1-\alpha^{f} \tau^{F}+D\right]^{2}} \frac{\gamma^{F}}{\gamma^{M}}
$$

In the absence of any transfer from sons and daughters, i.e. $\tau^{F}=\tau^{M}=0, \frac{\delta c_{1}^{f}}{\delta D}<0$ even when $\gamma^{F}=\gamma^{M}$. An increase in dowry raises the relative neglect even when parents do not have an implicit son preference. The same is true when transfers are made only by sons.

However, when sons and daughters both make transfers to parents in the second period, $\frac{\delta c_{1}^{f}}{\delta D}<0$ as long as $\alpha^{f}<1$ i.e. male wages are higher than female wages. If female wages are higher than male wages, then higher transfers from daughters in the second period offsets the adverse effect of increases in dowry payments.

In the presence of intrinsic son preference, an increase in dowry would reduce relative expenditure on girls to a greater extent.

\subsection{Relative wages and relative expenditure on girls}

The expenditure on daughters relative to sons, respond to relative wages in the following way:

$$
\frac{\delta c_{1}^{f}}{\delta \alpha f}=\frac{\tau^{F}\left[1-\tau^{M}-D\right]}{\left[1-\alpha^{f} \tau^{F}+D\right]^{2}} \frac{\gamma^{F}}{\gamma^{M}}
$$

When $\tau^{F}=0$, relative expenditure on daughters does not respond to relative wages, $\frac{\delta c_{1}^{f}}{\delta \alpha^{f}}=0$. Since there is no transfer from daughters in the second period, and increase in female wages does not benefit the parents. In a social set up where only sons transfer income to parents and daughters do not transfer income to parents, a change in returns to female labor does not have any impact on the relative expenditure on daughters.

When $\tau^{F}, \tau^{M}>0, \frac{\delta c_{1}^{f}}{\delta \alpha^{f}}>0$ as long as $\tau^{M}+D<1$. When relative female wage increases, parents 
receive higher amounts of transfer from daughters as $c^{F}$ increases. However, at high values of transfer from boys, $\tau^{M}$, parents are reluctant to cut back on $c^{M}$ since the trade off between total amounts of transfer from boys versus girls increases. Similarly at high rates of dowry, the increase in total transfers from daughters, $\tau^{F} \alpha^{F} c^{F}$, due to an increase in $c^{F}$ is offset by the increase in total dowry payments, $D c^{F}$.

Thus industrialization can affect sex ratio by changing the value of daughters relative to sons either in the labor market or in the marriage market or both, even in the absence of any son preference.

\subsection{Household Income and relative expenditure on girls}

Finally, in the presence of son preference industrialization might also affect relative deprivation of girls by changing household income. Suppose industrialization increases household income, A. Then both $c_{1}^{F}$ and $c_{1}^{M}$ would increase as long as they are normal goods. However, if parents have a pre-existing preference for sons, $c_{1}^{M}$ would increase more than $c_{1}^{F}$ and we would observe a relatively higher deprivation of girls in response to industrialization. 6 On the other hand, if household income falls as a result of industrialization, and if $c_{1}^{F}$ becomes a luxury good at lower incomes then the households would redistribute away the scarce household resources from the daughter to the son.

\footnotetext{
${ }^{6}$ The income effect could also be non-linear such that expenditure on boys grow faster than that of girls up to a certain level of income, beyond which expenditure on girls catch up. For instance, Oster 2009, finds that vaccination of boys increase much more than that of girls with higher access to immunizations and vaccines but the gap falls at even higher availability of immunization centers.
} 


\section{Background: Trade reforms and industrial growth}

Like many developing countries, import-substituting industrialization was one of India's development strategies from the 1950s to the early 1980s. A complex regime of import licensing requirements along with other barriers to trade kept the Indian economy fairly insulated from international competition. Around the late 1980s the government embarked upon an effort at economic reforms including reducing barriers to trade, especially allowing imports of capital goods. However, while a reduction in the barriers to trade and the de-licensing process in India started in the mid 1980s when Rajiv Gandhi was elected the prime minister after a series of political crisis, the major breakthrough came about only in 1991 after the assassination of Rajiv Gandhi and election of the new leader, Narasimha Rao. The 1991 reforms was a follow up of the macroeconomic crisis of the late 1980s, whereby India was conditioned to implement a structural adjustment program in return for a stand-by arrangement with the IMF.

The maximum tariff was reduced from 400 percent to 150 percent in July 1991 (Hasan et. al. 2003). After the initial slashing of tariffs in 1991 there was a gradual reduction in tariffs through 1997. Subsequent reductions saw the maximum tariff down to roughly 45 percent by 1997-98. The average effective tariff rate was reduced from about $86 \%$ in $1989-90$ to about $40 \%$ after the initial tariff cut in 1991, and further to about 30\% in 1999-2000 (Goldar, 2002). While the standard Heckscher-Ohlin-Stolper-Samuelson framework predicts that lowering of trade barriers would lead to an increase in demand for skilled workers in the developed countries and unskilled labor in developing countries, in reality the effect of trade liberalization on manufacturing employment would depend on the social and physical infrastructure of the country, labor market conditions like the excess labor or dualistic labor markets and type of specialization - import competing or export oriented. $^{7}$

In fact, previous evidence on the impact of trade reforms on industrialization in India provides

\footnotetext{
${ }^{7}$ Ghose (2000) discusses the theoretical implication of trade liberalization on employment and wages in details
} 
ample evidence on the growth in productivity and employment of the manufacturing sector following trade liberalization in 1991. For e.g. Goldar $(2000,2002)$ and Tendulkar (2000), among others, find evidence of acceleration in employment growth in the post-reform period both at the aggregate manufacturing level and for most two-digit industries. Table-3A reports estimates of employment growth in various industrial groups and aggregate manufacturing. As has been noted by several authors, a large part of the employment growth was driven by export oriented industries due to the large growth in labor intensive manufacturing exports after trade liberalization. Estimates suggest that employment growth rate in the manufacturing sector increased from $-.12 \%$ to $2.92 \%$ per annum while in export oriented industries it increased from $-0.57 \%$ to $3.36 \%$ per annum consequent upon tariff cuts in 1991 (Goldar, 2002). Table 1, Appendix 2, providing employment growth estimates across consumer, intermediate and capital goods industries also indicates a marked increase in all three industry types in '90s. Compared to a growth rate below 8\% per annum between 1980 and '90, exports grew at a rate of more than $25 \%$ after the reforms (Pandey, 2004). Along with employment, trade liberalization led to an increase in the both levels and growth of firm productivity (Topalova, 2004).

While these estimates are primarily based on time series data, using the NSS data between 1987 and 1999, I create a district level panel of the fraction of employment in the industrial sector. Results from a fixed effects model confirm that trade openness led to significant increase in employment in the non-agricultural sector. Details on the estimation of net tariff and non-agricultural employment are provided in section 5. Table 3B, column 1, shows the effect of net tariff reduction on the proportion of employment in non agriculture. It shows that a 10 percentage point fall in tariff rate, increased proportion of the population employed in the non-agriculture sector by 4 percentage points. I find similar results by using employment in non-agricultural occupational category instead of non-agricultural industrial classification, reported in column 2.

In this paper I use this exogenous shift in trade policy as a proxy to evaluate the impact of industrialization on relative female survival. Even though tariff changes continued to take place in 
the later phases between 1995 and 1997, I use only the initial structural break of 1991. An analysis of the subsequent reduction between 1995 and 1997 would be confounding since they cannot be taken as exogenous knowledge to the households anymore.

\section{Empirical Strategy}

Few studies in the past that have looked in to the effect of industrialization on the gender inequality in survival, correlate district level measures of industrialization at different points of time with sex ratio in the 0-4 age group in that district. The difficulty with these studies is that even after controlling for time and district fixed effects, there might be omitted variables that are correlated with industrialization that also affect gender inequality. For example, a growing supply of educated labor may trigger greater degree of industrialization in a region and also affect the sex ratio. However, if growth in industrialization is an exogenous shock determined by unexpected government policies then it will be independent of the omitted variables. Since liberalization in 1991 led to different degrees of tariff cuts in different industries and there was a wide variation in location of specific industries across different districts in India, the effective tariff decline varied widely across different districts. I utilize this variation in tariff reduction to estimate the effect of a child's exposure to trade policies on relative survival chances of female children. Particularly, using a cross section of children born between 1980 and 1999, I linked the probability of observing a male child in a family with district-level measures of changes in tariff protection following the 1991 reforms. The time and district of birth of a child and the percentage decline in tariff in district of birth determine the extent to which the decision-making households are exposed to the reform. This strategy enables us to identify the effect of industrial growth around the time of the trade reform. Thus if the identification strategy is correct we would expect it to affect only the cohorts born close to and after the reform. If the identification is spurious, for e.g. it is driven by unobserved factors in regions of high tariff decline or is a part of a trend, then we would expect that the effect of a tariff 
decline to be reflected on all cohorts born in regions with higher tariff decline.

\subsection{Estimation Specification}

Formally, in a strategy similar to Duflo (2001), I estimate in a difference-in-difference framework the effect of trade reforms on the relative survival chances of female children who are exposed to the reforms. ${ }^{8}$ Since children in the below 4 age group are most sensitive to health care and nutrition deficiencies, children born after 1987 are more likely to be exposed to differential treatment from parents due to the trade reforms. ${ }^{9}$ This implies that the degree of policy exposure varies by the cohort of birth. The degree of exposure also varies with the intensity of reforms, as measured by the percentage of tariff decline in a region. Combining these two sources of exposure we can estimate the effect of trade reforms on female survival according to the following model.

$$
M_{\text {ihdt }}=\alpha_{1}+T_{d} * \text { Young }_{i} \beta_{1}+X_{h} \delta_{1}+\gamma_{1 d}+\phi_{1 t}+\varepsilon_{i h d t}
$$

where, $M_{i h d t}$ is the event that child $\mathrm{i}$ born to household $\mathrm{h}$ in district $\mathrm{d}$ and belonging to birth cohort $t$ is male. I construct the dependant variable following Rose (1999) as the probability of being male or female conditional on survival at the time of the survey. ${ }^{10} T_{d}$ is the percentage tariff decline in district $\mathrm{d}$ after the 1991 reform, calculated from the base pre- reform tariff rate. Young ${ }_{i}$ indicates a dummy for whether child i belong to the younger cohort (i.e. born after 1987) which would be affected by any change in parental behavior due to the reform. $\gamma_{1 d}$ is the district fixed effect that differences out time invariant district characteristics; and $\phi_{1 t}$ is the cohort of birth fixed effect that differences out any trend effect that are invariant across all districts. $X_{h}$ represents house-

\footnotetext{
${ }^{8}$ This methodology has also been used by other authors, including Card and Krueger (1994), to estimate the impact of school quality on educational achievement and labor market outcomes. A more recent adoption of the strategy is by Chen an Zhou(2007) to estimate the impact of famine on the health of the affected.

${ }^{9}$ The literature on gender inequality in survival ubiquitously focuses on the sex ratio in the 0-4/0-5 age group as discrimination is likely to be most influential in affecting relative mortality during these early ages

${ }^{10}$ This reflects a measure of female deficiency due to both prenatal sex selection and higher relative mortality.
} 
hold specific demographic controls (dummies for household head's education, whether household belongs to schedule caste/tribe and household standard of living index). In the analysis, I include only those children for whom the first sibling was born in 1980 or later enabling me to observe complete families. ${ }^{11}$ The coefficient on the interaction between child i's cohort of birth and the intensity of tariff decline in the corresponding district of birth measures the effect of trade reforms on relative survival of the females. In particular, a positive $\beta_{1}$ implies that the probability of female survival, in a cohort exposed to the reform, decreased due to a greater degree of industrialization, where trade policy serves a proxy for industrialization.

While the above strategy measures the overall impact of tariff decline on the younger cohort who are likely to be affected by the policy change, it cannot outline the differential effect that the policy might have on each cohort. Specifically, in accordance with the earlier literature on son preference which emphasizes that sex discrimination is most critical in the 0-4 age group, we assume that only the cohorts born after the reform and those in the below 4 age group at the time of the reform would be affected. However, it is quite possible that the effect of trade reforms varied by cohort. To measure differential impact of trade reforms on different cohorts, I estimate an unrestricted coefficient model allowing the effect of trade policy on relative female survival to vary by year of birth. Specifically, I estimate the following equation:

$$
M_{i h d t}=\alpha_{1}+\sum_{q=2}^{19}\left(T_{d} * c_{i q}\right) \beta_{1 q}+X_{h} \delta_{1}+\gamma_{1 d}+\phi_{1 t}+\varepsilon_{i h d t}
$$

Where $M_{i h d t}$ is a dummy variable if the living child born in household h district $\mathrm{d}$, cohort $\mathrm{t}$ is a function of: the interaction term between $T_{d}$, the extent of decline in effective district tariff rate in district $\mathrm{d}$ and $c_{i q}$, a variable which indicates if child $\mathrm{i}$ is born in year q. $\gamma_{1 d}$ again is the district fixed effect and $\phi_{1 t}$ is the cohort of birth fixed effect. The dummy variable for the 1980 cohort and all of its interactions are dropped. Each coefficient $\beta_{1 q}$ can be interpreted as an estimate of the impact of

\footnotetext{
${ }^{11}$ There are very few observations in the data for families where the first child was born before 1980
} 
the trade reform on the survival chances of male children as opposed to female children in cohort q.

Equation (4.1) assumes that relative survival chances of male children compared to female children should have affected cohorts born close to and after the reform. The exact timing of the response in relative survival will depend on the nature of sex discrimination. If sex selection was conducted by infanticide or pre natal selection, then the reform should only affect sex ratios of cohorts born after the reform. However, if sex selection is conducted by negligence in childhood, then the reform can also affect sex ratios of children who were born a few years before it. To see if the latter effect is at work, in other words, if reform increased early childhood discrimination against girls, we need mortality data by gender. DHS data does provide detailed birth history of each woman interviewed. From the birth history records I construct a subsample of death records to see if female children exposed to the reform have higher probability of death in areas with higher tariff decline. However, due to the limited number of observations on death records of children, I cannot estimate the unrestricted model in equation (4.2). Instead, I pool the records of children born to the interviewed mothers and who died in the early years of childhood and estimate a specification similar in spirit to equation (4.1). Specifically, I estimate:

$$
F_{\text {ihdt }}=\alpha_{1}+T_{d} * \text { Young }_{i} \beta_{1}+X_{h} \delta_{1}+\gamma_{1 d}+\phi_{1 t}+\varepsilon_{i h d t}
$$

where, $F_{\text {ihdt }}$ is the probability of being female in the subsample of children who died within the first few years of life. Young $i$ is a dummy indicating whether the dead child belonged to the younger cohort, which would have been affected by the trade policy. Moreover, the biological literature on gender specific mortality of children suggests, that in infancy girls have a relative biological advantage over boys, so that we usually see an excess of male deaths. While this biological advantage continues for the entire phase of childhood, the biological difference subsides with 
age. ${ }^{12}$ Since male mortality is generally much higher in infancy (below 1 year of age), I restrict my analysis to children who died after infancy, at ages more than 1 year.

\section{Data}

The empirical estimation in this paper relies primarily on the 1999 round of the Demographic and Health Survey (also known as National Family and Health Survey) conducted in India with aid from USAID. It provides complete birth history of 90,303 ever-married women in the age group of 15-49. I focus on all children born in and after 1980, which accounts for $95 \%$ of the data. To observe complete families in terms of children ever born, I keep only those observations where the first child is born in and after 1980 and their corresponding siblings. Using information on the district of birth of each child, I matched the individual survey data with district level estimates of percentage tariff decline during 1991. Since the transition from traditional to industrial economy is relevant mainly for the rural sector, I limit the analysis to the rural households. Table-2, Panel A, outlines the average demographic and occupational characteristic of the population in this sample. On an average there are 3 children in a household. Hindus comprise about $77 \%$ of the population. The DHS data do not provide information on incomes. Instead, it includes a categorical index of wealth computed from information on various household asset holdings. About a third of the households belong to the lowest wealth category and a little more than a quarter belongs to the highest wealth category. About $40 \%$ of the households are employed in agriculture followed by $37 \%$ in industry. However, in regions that experienced higher trade liberalization in 1991, $41 \%$ of the households are employed in industry as opposed to only $31 \%$ in regions with low levels of trade liberalization.

\section{Please insert Table 2 here}

\footnotetext{
${ }^{12}$ See Waldron (1985) for a discussion of the biological causes of higher male mortality in childhood. Bhuiya and Streatfield(1992) and Muhuri and Preston(1991) also discuss the prevalence of sex discrimination after infancy.
} 
For constructing the tariff measure I use custom duty data obtained from the World Integrated Trade System (WITS) database which provides the data at the 6-digit HS (Indian Trade Classification Harmonized System) code level. These HS codes are then matched with the 3 digit NIC codes using the concordance of Debroy and Santhanam (1993). I use the tariff reduction in the manufacturing sector. The tariff measure used in this paper is in line with Topalova (2004). Since the fall in protection was identical across all regions in India, but varied across industries, the tariff measure exploits district level variation in industrial composition prior to the 1991 reforms. Specifically, district d's tariff at time $\mathrm{t}$ is measured by weighting the tariff in industry $\mathrm{j}$ and time $\mathrm{t}$ by the pre-reform employment share of industry $\mathrm{i}$ in district $\mathrm{d}$. Thus tariff in district $\mathrm{d}$, time $\mathrm{t}$ is given by

$$
\begin{aligned}
\text { Tariff }_{d t} & =\sum_{j} w_{j d} * \text { tariff }_{j t} \\
\text { where }_{w_{j d}} & =\frac{\text { employment }_{j d}}{\sum_{j} \text { employment }_{j d}}
\end{aligned}
$$

I compute weighted tariff in each district d in 1991 by using tariff data from 1991. For tariff measure prior to the reform I use tariff duty data for year 1990, the earliest year for which tariff data is available. Finally I take the percentage change in tariff between pre reform and 1991 as a measure of the intensity of trade reform in a district in 1991. The average tariff rates in the manufacturing sector are outlined in Table 2, Panel B. On an average tariff declined by almost $30 \%$ after the first phase of liberalization in 1991. It is this phase of the liberalization shock that we use in our analysis. Since this measure of tariff uses district specific employment weights determined prior to the trade reform, changes in industrial composition after the policy change that are result of the tariff changes do not affect the measure of exposure to trade reforms (Topalova 2003). 
Sex specific wage data comes from 3 rounds of National Sample Survey (NSS) covering the time period before and after the trade reforms. The NSS is a repeated cross section at the household level which collects a broad set of data on sampled households every 5 years. It's a nationally representative sample covering all states. I use the Employment and Unemployment rounds of the survey available for the years 1983, 1987-88, 1993-94 and 1999-2000. Apart from wage data, I use them to construct estimates of sex ratio and non-agricultural employment share at the district level.

Finally, I use the Rural Economic and Demographic Survey of NCAER to obtain Dowry data. It is a nationally representative longitudinal survey covering demographic, economic and health information for approximately 7500 households distributed over 100 districts spread over the 16 major states of India. Using retrospective marital information I create a panel of individuals married over various points of time and link the individual marriage payments data to the district level measure of trade liberalization.

\section{Results}

\subsection{Industrialization and Son Preference}

Table-1 lists the OLS estimates from a regression of district level sex ratio on the fraction of non-agricultural employment from 1987-1999 using the NSS. In all these results the causal interpretation depends on the assumption that there is no unobserved variation or omitted variables in these regressions that might be correlated with the error term. However, these assumptions are unlikely to hold. First, growth in education might determine the supply of educated or skilled labor in a district and hence, to an extent, industrialization. Growth in education might, at the same time, temper traditional values of son preference. ${ }^{13}$ While Table 1 has a control for litreacy,

\footnotetext{
${ }^{13}$ Shastry, 2008, in her working paper discusses how districts with a more elastic supply of English skills experienced greater growth jobs requiring such skills
} 
it is a poor proxy for educational improvements. If we cannot fully control for the parental skill, we would underestimate the effect of industrialization on the female to male sex ratio. Previous literature analyzing the effect of economic development on relative female survival controls for a variety of factors to overcome this problem. However, there might still be unobserved variables driving the bias. Since the trade liberalization polices of 1991 potentially had a large impact on industrialization and at the same time were unexpected, I use it as an exogenous shock to address these concerns of endogeneity.

\subsection{Baseline Estimates}

Table 4 shows the estimation results from regression equation (4.1). The previous literature emphasizes that children of higher birth order are more likely to be male. This means that if we take a sample of children born in year $\mathrm{t}$ and onwards, we would be selecting in the group more children who are of higher birth order and this may bias our results. Hence, I restrict the analysis to all those children for whom the first sibling was born in 1980 or later enabling me to observe complete families. ${ }^{14}$ Column 1 shows the results for the entire sample of living children during the time of the survey in 1999. "Young" refers to the fact that the child under observation belongs to the younger cohort which is exposed to the trade reforms. Specifically, I define "Young" as an indicator taking value 1 when the individual was born between 1988 and 1996, below 4 years of age in 1992, and 0 when the person was born between 1980 and $1988 .{ }^{15}$ It shows that among children born in the younger cohort, hence exposed to the reform period, those born in regions experiencing higher trade openness (greater degree tariff decline) are more likely to be male. According to

\footnotetext{
${ }^{14}$ I checked other years prior to 1980 for which data on birth records are available. However, after retaining only those children where the oldest sibling is born in year x, records for all x prior to 1980 are insufficient to be included in the analysis.

${ }^{15}$ I do not include the cohorts born after 1996 since in 1997 there was a second phase of significant tariff cut, which I do not include in my analysis. It cannot be expected to be exogenous with households forming expectations about future tariff cuts. Hence, pooling later cohorts in the "Young" group might confound the exogenous effect of tariff change in the 1 st phase. The second phase of tariff reduction reduced across industry variability in tariff compared to the first phase.
} 
estimates, two observationally equivalent households with same degrees of pre-existing son preference but belonging to districts that differ in the rate of tariff reduction, or trade liberalization, by 30 percentage points, are predicted to differ in their respective probabilities of having a male child by approximately 6 percentage points. ${ }^{16}$ The underlying assumption here is that individuals born between 1988 and 1996 are affected by the reform. To see which cohorts are indeed affected by the policy change of 1991, I estimate equation(4.2). The unrestricted coefficient estimates are presented in column (1) of Table 5 for the whole sample. The estimates suggest that for children born close to and after the policy change (1987 onwards) the male bias increases significantly with the extent of percent tariff reduction. This indicates that apart from prenatal selection, that would affect cohorts born after the reform, there is possibly differential treatment of females who are still in their early childhood during the 1991 tariff cut and hence more susceptible to differential child care provision and nutrition. On the other hand, tariff decline did not have any significant effect on the cohorts born between 1981 and 1987. In other words the tariff decline did not affect cohorts that were born much before the first round of liberalization and hence not exposed to the reform. This finding lends support to the causal effect of the change in trade policy and confirms that the estimates in Table 4 are not driven by pre-existing differential trends between high and low tariff-change regions. It affected only those cohorts that were most likely to be exposed to the reform.

Please insert Table 4 here

\subsection{Absence of Elder Male Sibling}

The literature on sex ratio emphasizes on the role of siblings in son preference. In particular, it is well established that preference against a daughter is strongest in the absence of a son (Bhat and Zavier 2007). To test this hypothesis, I estimate the effect of the trade reform on the probability

\footnotetext{
${ }^{16}$ The average rate of tariff decline is approximately $30 \%$, as shown in Table 2-PanelB.
} 
of having a male child in the absence of an older male sibling. The unrestricted estimates are presented in column 2 of Table 5. However, the results are not significantly different from zero except for the cohort of 1991.

\section{Bias from selective migration}

Any analysis with spatial variation is fraught with possibilities of selective migration. The analysis above does not account for the possibility of increased migration that might have followed trade liberalization. The underlying assumption is that a woman interviewed at her current place of residence has stayed there ever since her children were born so that the region of birth of the children is same as the region of the current residence of their mother. However, if migration patterns differed systematically between high and low trade districts then the OLS estimates could be capturing the effects of migration due to trade liberalization. In particular, families with relatively more male children might have moved to areas which experienced greater industrialization due to tariff reduction with an expectation of greater child-labor avenues for male children in the industrial sector or with an expectation of better future earnings when the children join market work as adults. In that case the OLS estimates would be upward biased - capturing the effect of selective migration. To address this issue I need information on the region of birth of the children, and hence history of the woman's earlier place of residence. Unfortunately, the DHS data do not provide any information on the district of past residence. The only relevant question asked is about the length of stay at the current place of residence. Since the survey year is 1999 and the liberalization policy was introduced in 1991, the concern is mainly about selective migration that took place between these years as a response to the policy change. So I re-estimate equation (4.1) over a subsample of ever-married females who have stayed in their current place of residence (i.e. in 1999) for more than 9 years. This implies, we are eliminating all those birth records where the mother might have migrated to (from) areas that experienced greater (lower) tariff cut. Table- 6 column 1 provides 
the details for each cohort for the whole sample as well. The coefficients in this subsample, rid of migration effects, suggest that the OLS estimates without migration correction are not upward biased. In fact the estimates in the migration cleaned sample are higher on average.

\section{Mechanisms}

As noted in section 2, there are several channels through which trade policies could have affected household preferences. In particular, changes in poverty, change in value of women either in the labor market or in the marriage market, might affect relative expenditure on daughters. In what follows, I present supporting evidence on the potential channel through which trade liberalization might have intensified the discrimination against girls in India.

\subsection{Poverty}

Theoretically, the link between poverty and sex ratio suggests that households facing tighter income constraints might prefer to have sons than daughters where sons are more likely to participate in market work. Topalova (2005) and Topalova et al (2007), using National Sample Survey data from 1983-1997, finds that districts which were more exposed to trade reforms experienced smaller poverty reduction than the national average. So it is possible that in districts that experience a relatively greater decline in tariff, households are relatively more credit constrained and observe a relatively greater neglect of girls. Past evidence on the relationship between household income and son preference is mixed. Data from India suggests that the richest states of North India are also the ones that always had the lowest proportion of females in the $0-4$ age group. ${ }^{17}$ While macro level studies find an inverse correlation between poverty and relative female survival across states, household level investigation also confirm a trend of more masculine child sex ratio as one

\footnotetext{
${ }^{17}$ At the same time, Kerala, one of the poorest states in India, performs the best in terms of relative female survival. All related studies in India, from Sen (1990) to Bhat and Zavier (2007) acknowledge this notable feature.
} 
ascends the income distribution curve (Agnihotri 2000, Siddhanta et al 2003). On the other hand, Qian (2007) finds that total household income does not affect relative female survival. Drze and Sen (1998) also conclude that there is little evidence that income has a significant relationship to gender differentials. Given the mixed evidence on the relationship between poverty and son preference, I control for household standard of living index in the equations (4.1) and (4.2). DHS data reports whether a household is in the low, middle or high standard of living group. I include dummies for the low and high index groups. The results, outlined in column 2 of Table 4 and column 3 of Table 5, show that controlling for household income does not alter the results in column (1). The coefficients are not significantly different from each other.

\subsection{Wages}

I use wage data from the NSS rounds of 1987-88 and 1997 in order to find out how male and female wages responded to trade liberalization using the following regression. ${ }^{18}$

$$
\text { lnwage }_{\text {idt }}=\alpha_{2}+\text { Tariff }_{d t} \beta_{2}+X \phi_{2}+\gamma_{d}+\tau_{t}+\eta_{\text {ihdt }}
$$

Where, lnwage $_{i d t}$ represents $\log$ of wage of individual $\mathrm{i}$ in district $\mathrm{d}$ and time $\mathrm{t}$. Tariff $f_{d t}$ represents the district tariff rate in time t. $\mathrm{X}$ is a vector of household and individual controls like religion, caste and age of the individual. $\gamma_{d}$ is a district fixed effect and $\tau_{t}$ is a year fixed effect. $\eta_{\text {ihdt }}$ is an idiosyncratic error term. Since trade openness is expected to affect skilled and unskilled jobs differently, I run the regression on the subsamples of literates and illiterates. Table (9) shows the effect of tariff on wages. Results in column (1) imply that lower tariff is associated with higher wages for skilled male labor. However, I do not find any effect of tariff on wages of unskilled labor. On the other hand for female wages, I do not find any significant effect of tariff in either the skilled or the unskilled group. Thus it is possible that tariff reduction led to an increase in

\footnotetext{
${ }^{18}$ I could not include Round 1993-94 since it does not provide district identifiers.
} 
discrimination towards girls due to a reduction in relative female wages, at least for the skilled population. However, in the context of India, where married daughters do not transfer resources to their parents, a change in relative wages is less likely to be an important determinant of sex selection. $^{19}$

\subsection{Dowry}

Anderson (2003) argues that in a socially segregated economy like India where marriages are restricted within each caste,industrialization of the economy increases within group income inequality and puts an upward pressure on dowries (groom price). This leads to an increasing demand for better quality grooms within each group, thus pushing up the groom price. Recent evidence from India suggests that there has been noticeable dowry inflation in the past few decades. ${ }^{20}$ Most interestingly, apart from the general inflation in dowries, Rahman and Rao (2004) dispute the idea that the regional patterns (North versus South) in the existence of dowry identified by Dyson and Moore (1983) still hold. They note that in modern India, Southern brides are as likely to pay dowry (and pay as much) as Northern brides (Pande and Astone, 2007) If regions with higher tariff reduction experience higher dowry inflation then dowry might be a driving factor behind a stronger discrimination against girls in these regions. In a regression similar to that of relative survival we can estimate how dowry payments changed in marriages that happened after the policy change, and hence exposed to the reform, compared to the marriages that took place before the change in policies, and hence unexposed to the reform. In other words, I compare dowries between marriages that happened strictly before and after the reform and also across districts with different intensity of tariff reduction in the following regression.

\footnotetext{
${ }^{19}$ In the context of India, Foster and Rosengweig (2001) note "the common inference from these findings (effect of women's labor market outcome on 0-4 sex ratio) that mother's earnings measure the returns to the investments in their daughters neglects the fact that the daughters when adults do not reside in the same village as the mothers."

${ }^{20}$ See Rao (1993), Srinivasan (2005)
} 


$$
\text { Dowry }_{m h d t}=\alpha_{3}+T_{d} * \text { Post }_{m h} \beta_{3}+X_{h} \delta_{1}+\gamma_{1 d}+\phi_{1 t}+\varepsilon_{m h d t}
$$

Where, Dowry ${ }_{m h d t}$ represents dowry paid (dowry received) in marriage m, of a daughter (son), of household $\mathrm{h}$ in district $\mathrm{d}$ and time t. $T_{d}$ as before represents the percentage tariff reduction in district d. Post is a dummy indicating whether marriage $\mathrm{m}$ in household $\mathrm{h}$ took place before or after 1992. If dowry increased with tariff reduction then we would expect $\beta_{3}$ to be positive. $X$ is a vector of individual controls. $\gamma_{1 d}$ and $\phi_{1 t}$ are household and year of marriage fixed effects. $\varepsilon_{i h d t}$ is an idiosyncratic error term. Since DHS does not ask questions related to dowry, I use the Rural Economic and Demographic Survey (REDS) longitudinal data which tracks 4500 households across India. I use annual CPI data at the state level for industrial workers from Central Statistical Organization of India to adjust for nominal dowry inflation. Moreover since the practice of dowry as a marriage payment is traditionally prevalent amongst the Hindus and not Muslims, I do the analysis separately for the two main religious groups. Lack of sufficient data doesn't allow me to restrict the sample to Muslims only; instead I take all other religion. However, Muslims comprise $70 \%$ of this group. Table (10) presents the results from the estimation of equation (8.2). Column 1 shows that after controlling for years of education, year of marriage fixed effects and household fixed effects, real dowries have increased with higher trade openness amongst Hindus, although the coefficients are imprecisely estimated. When I restrict to the sub-sample of high caste Hindus, who traditionally practice the custom of dowry, the coefficients are significantly larger. The estimates shown in column $3 \mathrm{a}$ of Table 10, are precise even in this small subsample. Tariff cut has no significant impact on dowry payments in marriages of other religious groups.

Please insert Table 10 here 


\section{Heterogeneity of Impact}

In the perspective of the above results, if dowry increase is responsible for a part of the parental discrimination towards daughters then we would expect relative female survival to decline more for Hindus compared to Muslims. Thus more insight into why trade policies might have worsened relative female survival could be obtained by examining its effect on different religious groups. In order to see if trade liberalization had differently affected these religious groups, Table 4 reports results from the interaction of the linear treatment variable with a set of dummy variables indicating a household's religion. In column 1b-1c of Table-4, I compare the effect of tariff cut on the probability of having a male child in Hindu and Muslim households respectively. Strikingly, I find that the results suggest significant discrimination against girls in Hindu households but the relative probability of having a male child remains unaffected for the Muslim households. This result seems to hold consistently across all specifications. For the unrestricted estimates the results are shown in Column (1a-1b) of Table 6. Once again, the results indicate a higher male bias for the cohorts exposed to reform but only in the Hindu subsample. The results are not significant for Muslims, indicating that the growing sex bias, as a fall out of the liberalization policies, was a particularly Hindu phenomenon. ${ }^{21}$ The results for the subsample of Hindus are presented in column- 4 of Table 4 and column-3 of Table 6 for the restricted and unrestricted estimations respectively. The results for the non-migrant Hindu households are presented in Table-4, column 6, for the base specification, and in Table 7, column 2, for the unrestricted specification. Non-migrant Hindu households are not statistically different from the overall Hindu population. I do a further check to see if the relative female survival in Hindu households responds to the sex selection situation discussed before. Table 4, column 4, shows the estimates for those children who are do not have elder male siblings and hence are more likely to be discriminated against according to gender. They are in fact greater than the estimates in column 3, the base specification for Hindu

\footnotetext{
${ }^{21}$ For other religions, number of observations are too few to add any valuable insights.
} 
households; implying that the effect of trade policies in reducing relative female survival chances is stronger when the child is in a sex selection situation. Table 6 , column $2 \mathrm{a}$, shows the effect in case of individual cohorts and again the coefficients are larger when the sample is restricted to children with no prior male sibling (compare with column 1a). Column $2 \mathrm{~b}$ shows that the bias does not exist for Muslim children in a similar situation. This implies that children born to households with elder female siblings are more likely to be male in districts with higher tariff decline compared to their counterparts in districts with lower average tariff cut. It is in accordance with our argument that parents observe a higher level of preference for sons in areas that face greater trade liberalizationparental selection of a child's gender is stronger in areas with high tariff cut we compare children who are in a sex selection situation. Trade liberalization is expected to affect the entire population irrespective of religious groups though poverty and wage increases. However, dowry is known to be a particularly Hindu phenomenon and hence is likely to affect son preference only for the Hindu households. The above results are suggestive of dowry being an important channel through which trade policies might have affected parental preference for sons.

\section{Early Childhood Mortality}

As mentioned earlier, the exact timing of the response in relative survival will depend on the nature of sex discrimination. The estimates in Table 5 and 6 indicates that the cohorts born close to but before the reform were also affected by the policy change and we assumed that it would have been due to higher childhood mortality amongst these cohorts. However, industrialization might affect the sex ratio due to greater availability of sex selection technology in the more developed regions and hence only through greater pre-natal selection and not through relative deprivation in childhood. In that case, the results for cohorts born before the policy change might actually be spurious. Thus it remains to be investigated whether trade reform actually led to higher childhood mortality of children, due, may be, to negligence. Female children are believed to have a relative 
biological advantage in survival due to better immunity systems. Thus any excess mortality of female children is considered to be an indication of discrimination. Table 8 shows the results from regression equation (4.3). Based on the evidence so far, the analysis restricts to the Hindu

households. The results in column (1) indicate that among children who died in the first few years of life, girls had a higher probability of death compared to boys in regions exposed to higher percentage tariff reduction. This suggests that growth in the availability of sex selection technology was not the only reason why the sex ratios diverged between regions with different degrees of trade openness. Negligence of female children was also one of the possible mechanisms driving the lower survival chances of female children due to the policy change.

\section{Conclusion}

The above analysis suggests that industrialization played a significant role in shaping or aggravating already existing parental preference over children's gender. The small previous literature addressing this question does not account for the endogeneity of industrialization. In this paper I exploit an exogenous shock to industrialization in India in 1991 to retrieve the causal link between industrialization and the growing female deficit. I find that trade liberalization reduced the survival chances of female relative to male children. Another interesting result that emerges from the analysis is the difference in the impact of trade liberalization on different religious groups. Specifically, while relative female survival changes significantly in the Hindu households, there is no change in the behavior of Muslims. One possible explanation is the effect of trade liberalization on Dowry inflation. The results indicate, there was a relative increase in real Dowries paid in Hindu marriages, while the coefficients were opposite in sign and insignificant for other religions. Thus although it is difficult to point to any specific cause that might have triggered a stronger son preference as a result of the industrialization process, supplementary evidence suggests that change in the relative value of women in the marriage market might have played an important role in determining the 
effect of industrialization. In contrast, economic factors probably were less instrumental in affecting relative female survival through trade openness. Whatever the mechanism, it is likely that the continued process of industrialization in many of these traditional economies, like India or China, might aggravate the mortality differential between males and females. It is thus important to incorporate these indirect adverse effects while doing a cost benefit analysis and to design policies to offset the unwanted by products of trade liberalization. 


\section{References}

Agnihorti, S. (2000). Sex ratio patterns in the Indian population: A fresh exploration. Sage Publications Ltd.

Anderson, S. (2003). Why dowry payments declined with modernization in Europe but are rising in India. Journal of Political Economy, 111(2), 269-310.

Bardhan, P. K. (1974). On life and death questions. Economic and Political Weekly, , 12931304.

Becker, G. S. (1991). A treatise on the family Harvard Univ Pr.

Bhattacharya, P. C. (2006). Economic development, gender inequality, and demographic outcomes: Evidence from india. Population and Development Review, 32(2), 263-292.

Burgess, R., \& Zhuang, J. (2000). Modernisation and son preference.

Chakraborty, T., \& Kim, S. (2010). Kinship institutions and sex ratios in india. Demography, 47(4), 989-1012.

Debroy, B., \& Santhanam, A. (1993). Matching trade codes with industrial codes. Foreign Trade Bulletin, 24(1), 5-27.

Duflo, E. (2000). Schooling and Labor Market Consequences of School Construction in Indonesia: Evidence from an Unusual Policy Experiment,

Edlund, L. (1999). Son preference, sex ratios, and marriage patterns. Journal of Political Economy, 107(6), 1275-1304.

Foster, A., \& Rosenzweig, M. R. (2001). Missing women, the marriage market and economic growth. Downloaded from Http://adfdell.Pstc.Brown.edu/papers/sex.Pdf,

Ghose, A. K., My iLibrary, \& International Labour Office. Employment Sector. (2000). Trade liberalization and manufacturing employment International Labour Organization. 
Goldar, B. (2002). Trade liberalization and manufacturing employment: The case of India. ILO Employment Paper 2002/34, 92-2-113080-0[ISBN],

Hasan, R., Mitra, D., \& Ramaswamy, K. (2007). Trade reforms, labor regulations, and labordemand elasticities: Empirical evidence from India. The Review of Economics and Statistics, 89(3), 466-481.

Norberg, K. (2004). Partnership status and the human sex ratio at birth. Proceedings of the Royal Society of London. Series B: Biological Sciences, 271(1555), 2403.

Oster, E. (2005). Hepatitis B and the case of the missing women. Journal of Political Economy, 113(6), 1163-1216.

Pande, R. P., \& Astone, N. M. (2007). Explaining son preference in rural India: The independent role of structural versus individual factors. Population Research and Policy Review, 26(1), 1-29.

Pandey, M. (2004). Impact of trade liberalisation in manufacturing industry in India in the 1980s and 1990s Indian Council for Research on International Economic Relations, New Delhi Working Papers 140,

Qian, N. (2008). Missing women and the price of tea in china: The effect of sex-specific earnings on sex imbalance. The Quarterly Journal of Economics, 123(3), 1251.

Rao, V. (1993). Dowry 'inflation’ in rural India: A statistical investigation. Population Studies, 47(2), 283-293.

Rose, E. (1999). Consumption smoothing and excess female mortality in rural India. Review of Economics and Statistics, 81(1), 41-49.

S., S., D., N., \& B., A. S. (2003). Special statistics - 36: Sex ratios and 'prosperity effect' what do NSSO data reveal? Economic and Political Weekly, 38(41), pp. 4381-4404. Retrieved from http://www.jstor.org/stable/4414140 
Sen, A. (1990). More than 100 million women are missing. New York Times, Volume 37, Number 20, Dec. 20.

Waldron, I. (1985). What do we know about causes of sex differences in mortality? A review of the literature. Population Bulletin of the United Nations, (18)(18), 59-76.

Table 1

\begin{tabular}{lllll}
\hline \multicolumn{5}{c}{ Dependent variable : Proportion of males in the 0-4 age group (1987-1999) } \\
\hline & $(1)$ & $(2)$ & $(3)$ & $(4)$ \\
\hline share of non-agriculture & $0.082 * *$ & $0.08 * *$ & $0.079 * *$ & $0.073 *$ \\
& $(0.037)$ & $(0.038)$ & $(0.038)$ & $(0.039)$ \\
proportion of illiterate & - & -0.013 & -0.020 & -0.014 \\
proportion of backward & - & $(0.053)$ & $(0.057)$ & $(0.058)$ \\
social groups & - & 0.020 & 0.021 \\
& & & $(0.042)$ & $(0.042)$ \\
female labor participation & - & - & - & -0.015 \\
& & & & $(0.022)$ \\
Number of obs & 1089 & 1089 & 1089 & 1089 \\
$\mathrm{R}^{2}$ & 0.365 & 0.365 & 0.366 & 0.366 \\
\hline
\end{tabular}

Note: All specifications include district and year fixed effect. Standard errors in parentheses are clustered at the district level. 
Table 2: PANEL A

\begin{tabular}{cc}
\hline & DHS Sample \\
\hline & Mean \\
\hline Schedule caste/tribe & 0.327778 \\
Hindu & 0.779675 \\
\# of children & 3.324748 \\
& \\
Proportion low SOLI & 0.313471 \\
Proportion med SOLI & 0.464961
\end{tabular}

\begin{tabular}{lccc}
\hline \multicolumn{3}{c}{ Household head characteristics } \\
\hline Years of education & 5.12395 & & \\
Industry of & & high tariff fall & low tariff fall \\
Occupation & & 0.3589809 & 0.4850511 \\
\hline Agriculture & 0.420588 & 0.0877641 & 0.0672551 \\
Education & 0.077742 & 0.416411 & 0.3156503 \\
Industry & 0.367172 & 0.1368439 & 0.1320435 \\
Menial Services & 0.134498 & & \\
\hline
\end{tabular}

Table 2: PANEL B

\begin{tabular}{lllll}
\hline \multicolumn{5}{c}{ District Average Tariff Measures and its variation } \\
\hline & $\begin{array}{l}\text { Net tariff in } \\
\text { manufacturing } \\
\text { sector }\end{array}$ & SD & $\begin{array}{l}\text { Average } \\
\text { decline in } \\
\text { tariff }\end{array}$ & SD \\
\hline before 91 & 87.43782 & $(6.33)$ & & \\
1991 & 61.10069 & $(2.55)$ & 0.298 & $(0.037)$ \\
1997 & 34.25083 & $(2.55)$ & 0.439 & $(0.027)$ \\
\hline
\end{tabular}

Table 3A

Percentage growth rate per year in manufacturing employment, 1973-74 to 1997-98, by industry category:

\begin{tabular}{rrrrrr}
\hline & $\begin{array}{c}\text { Food, } \\
\text { beverages, } \\
\text { tobacco }\end{array}$ & \multicolumn{1}{c}{$\begin{array}{c}\text { Petroleum } \\
\text { products }\end{array}$} & $\begin{array}{c}\text { Export } \\
\text { oriented }\end{array}$ & $\begin{array}{c}\text { Import } \\
\text { competing }\end{array}$ & $\begin{array}{c}\text { All } \\
\text { manufacturing } \\
\text { Industries }\end{array}$ \\
\hline & & & & & \\
$1973-89$ & 1.41 & 5.26 & -0.57 & 2.8 & 1.6 \\
$1990-97$ & 2.56 & 6.09 & 3.36 & 2.67 & 3.09 \\
\hline
\end{tabular}


Table 3B

Effect of Tariff Rates on proportion of employment in non-agriculture

\begin{tabular}{lll}
\hline & $\begin{array}{l}\text { Employment in } \\
\text { nonagri industry }\end{array}$ & $\begin{array}{l}\text { Employment in } \\
\text { nonagri occupation }\end{array}$ \\
\hline Net Tariff & $\begin{array}{l}-0.004^{* *} \\
(0.001)\end{array}$ & $\begin{array}{l}-0.003^{* *} \\
(0.001)\end{array}$ \\
& $\begin{array}{l}0.446^{* * *} \\
(0.129)\end{array}$ & $\begin{array}{l}0.503^{* * *} \\
(0.053)\end{array}$ \\
constant & Yes & Yes \\
District FE & Yes & Yes \\
Year FE & & \\
R-square & 0.7396 & 0.803 \\
Obs & 1222 & 1222 \\
\hline
\end{tabular}

Note: Standard errors in parentheses are clustered at the district level. The results imply a fall in tariff, or more trade openness increases the share of non agricultural employment.

Table 4:

\begin{tabular}{|c|c|c|c|c|c|c|}
\hline \multicolumn{7}{|c|}{ Dependent variable: Indicator whether observed child is male } \\
\hline & 1a & $1 \mathrm{~b}$ & 2 & 4 & 5 & 6 \\
\hline & $\begin{array}{l}\text { Full } \\
\text { Sample }\end{array}$ & Full Sample & Full Sample & Hindu & Hindu & Hindu \\
\hline & & & & & $\begin{array}{l}\text { No elder male } \\
\text { sib }\end{array}$ & Non Migrant \\
\hline$\Delta$ Tariff*Young & $0.205^{*}$ & & $0.212 *$ & $0.280^{* *}$ & $0.349 * * *$ & $0.344 * * *$ \\
\hline & $(0.11)$ & & $(0.11)$ & $(0.12)$ & 0.13 & $(0.12)$ \\
\hline$\Delta$ Tariff*Young & & $0.0423 * *$ & & & & \\
\hline *Hindu & & $(0.021)$ & & & & \\
\hline Controls for SOLI & No & No & Yes & Yes & No & No \\
\hline Constant & $0.522 * * *$ & $0.522 * * *$ & $0.528 * * *$ & $0.523 * * *$ & $0.512 * * *$ & $0.520 * * *$ \\
\hline & $(0.003)$ & $(0.003)$ & $(0.0034)$ & $(0.006)$ & $(0.004)$ & $(0.004)$ \\
\hline Observations & 91731 & 91630 & 89801 & 71157 & 41106 & 59685 \\
\hline R-squared & 0.01 & 0.01 & 0.01 & 0.01 & 0.01 & 0.01 \\
\hline
\end{tabular}

Note: Sample consists of all children reported to be living by interviewed mother. $\Delta$ Tariff is the percentage change in tariff between pre (1989) and post reform (1991) tariff rates. All regressions control for a dummy indicating whether the household belongs to disadvantaged social group (Scheduled Caste or Scheduled Tribe). Standard errors are clustered at the district level. Regression includes District and Time fixed effects. 
Table 5: Unrestricted estimates

\begin{tabular}{|c|c|c|c|c|c|c|}
\hline \multicolumn{7}{|c|}{ Dependent variable: indicator whether observed child is male } \\
\hline Born in year & Whole Sample & & $\begin{array}{l}\text { No elder male } \\
\text { sib }\end{array}$ & & Whole sample & \\
\hline 1981 & 0.151 & $(0.28)$ & -0.0554 & $(0.48)$ & 0.144 & $(0.28)$ \\
\hline 1982 & 0.229 & $(0.30)$ & 0.399 & $(0.41)$ & 0.291 & $(0.30)$ \\
\hline 1983 & 0.119 & $(0.33)$ & 0.112 & $(0.51)$ & 0.134 & $(0.33)$ \\
\hline 1984 & 0.203 & $(0.31)$ & 0.290 & $(0.49)$ & 0.235 & $(0.31)$ \\
\hline 1985 & 0.366 & $(0.26)$ & 0.429 & $(0.42)$ & 0.370 & $(0.26)$ \\
\hline 1986 & 0.344 & $(0.24)$ & 0.199 & $(0.40)$ & 0.363 & $(0.24)$ \\
\hline 1987 & 0.389 & $(0.27)$ & 0.297 & $(0.39)$ & 0.427 & $(0.27)$ \\
\hline 1988 & $0.435 *$ & $(0.25)$ & 0.430 & $(0.44)$ & $0.445 *$ & $(0.25)$ \\
\hline 1989 & $0.576 * *$ & $(0.25)$ & 0.457 & $(0.41)$ & $0.584 * *$ & $(0.25)$ \\
\hline 1990 & 0.379 & $(0.30)$ & 0.319 & $(0.53)$ & 0.423 & $(0.30)$ \\
\hline 1991 & 0.319 & $(0.27)$ & $0.767 *$ & $(0.41)$ & 0.361 & $(0.27)$ \\
\hline 1992 & 0.199 & $(0.24)$ & 0.0401 & $(0.39)$ & 0.211 & $(0.24)$ \\
\hline 1993 & $0.611 * * *$ & $(0.22)$ & 0.377 & $(0.36)$ & $0.619 * * *$ & $(0.22)$ \\
\hline 1994 & $0.413 *$ & $(0.25)$ & 0.556 & $(0.38)$ & $0.417 *$ & $(0.24)$ \\
\hline 1995 & $0.599 * *$ & $(0.24)$ & 0.476 & $(0.33)$ & $0.598 * *$ & $(0.24)$ \\
\hline 1996 & 0.0699 & $(0.28)$ & 0.172 & $(0.40)$ & 0.0934 & $(0.28)$ \\
\hline 1997 & 0.147 & $(0.25)$ & 0.287 & $(0.42)$ & 0.137 & $(0.25)$ \\
\hline 1998 & 0.316 & $(0.24)$ & 0.0432 & $(0.43)$ & 0.330 & $(0.24)$ \\
\hline 1999 & 0.163 & $(0.36)$ & $1.410 *$ & $(0.78)$ & 0.208 & $(0.36)$ \\
\hline dshsli1 & & & & & 0.00183 & $(0.0036)$ \\
\hline dshsli3 & & & & & 0.00486 & $(0.0051)$ \\
\hline $\mathrm{SC} / \mathrm{ST}$ & & & & & -0.00260 & $(0.0035)$ \\
\hline Constant & $0.474 * * *$ & $(0.11)$ & 0.0952 & $(0.23)$ & $0.457 * * *$ & $(0.11)$ \\
\hline Observations & 106803 & & 59284 & & 105662 & \\
\hline R-squared & 0.01 & & 0.01 & & 0.01 & \\
\hline
\end{tabular}

All specifications include district and cohort fixed effect. Standard errors are clustered at the district level. 
Table 6: Unrestricted estimates for religious sub-samples

\begin{tabular}{|c|c|c|c|c|c|}
\hline \multicolumn{6}{|c|}{ Dependent variable: Whether Observed child is male } \\
\hline & 1a & $1 \mathrm{~b}$ & $2 \mathrm{a}$ & $2 \mathrm{~b}$ & 3 \\
\hline \multirow[t]{2}{*}{ Born in year } & Hindu & Muslim & Hindu & Muslim & Hindu \\
\hline & & & $\begin{array}{l}\text { No elder male } \\
\text { sib }\end{array}$ & $\begin{array}{l}\text { No elder male } \\
\text { sib }\end{array}$ & \\
\hline \multirow[t]{2}{*}{1981} & 0.213 & -1.619 & 0.106 & $-3.132 *$ & 0.217 \\
\hline & $(0.34)$ & $(1.11)$ & $(0.40)$ & $(1.62)$ & $(0.34)$ \\
\hline \multirow[t]{2}{*}{1982} & 0.552 & -0.598 & 0.436 & -2.845 & 0.575 \\
\hline & $(0.43)$ & $(1.37)$ & $(0.46)$ & $(1.97)$ & $(0.43)$ \\
\hline \multirow[t]{2}{*}{1983} & 0.217 & 0.599 & 0.421 & -0.651 & 0.179 \\
\hline & $(0.37)$ & (1.47) & $(0.44)$ & (1.80) & $(0.38)$ \\
\hline \multirow[t]{2}{*}{1984} & 0.386 & -1.662 & 0.476 & -1.808 & 0.426 \\
\hline & $(0.35)$ & (1.17) & $(0.45)$ & (1.86) & $(0.35)$ \\
\hline \multirow{2}{*}{1985} & 0.482 & 0.213 & 0.569 & -0.921 & 0.486 \\
\hline & $(0.31)$ & (1.28) & $(0.37)$ & $(1.55)$ & $(0.31)$ \\
\hline \multirow{2}{*}{1986} & 0.405 & 0.806 & 0.213 & -0.410 & 0.421 \\
\hline & $(0.28)$ & (1.12) & $(0.37)$ & (1.67) & $(0.27)$ \\
\hline \multirow[t]{2}{*}{1987} & $0.578 * *$ & -1.514 & $0.651 *$ & -1.032 & $0.612 * *$ \\
\hline & $(0.29)$ & (1.45) & $(0.36)$ & (1.82) & $(0.29)$ \\
\hline \multirow[t]{2}{*}{1988} & $0.641 * *$ & -0.418 & $1.102 * * *$ & -2.954 & $0.666 * *$ \\
\hline & $(0.27)$ & (1.23) & $(0.35)$ & (1.84) & $(0.27)$ \\
\hline \multirow[t]{2}{*}{1989} & $0.949 * * *$ & -0.465 & $0.811 * *$ & -2.084 & $0.917 * * *$ \\
\hline & $(0.27)$ & (1.07) & $(0.39)$ & (1.77) & $(0.27)$ \\
\hline \multirow[t]{2}{*}{1990} & $0.725 * *$ & -1.574 & $0.907 * *$ & $-2.904 *$ & $0.774 * *$ \\
\hline & $(0.33)$ & (1.18) & $(0.41)$ & (1.54) & $(0.33)$ \\
\hline \multirow[t]{2}{*}{1991} & $0.491 *$ & -0.438 & $0.627 *$ & -2.632 & $0.529 *$ \\
\hline & $(0.30)$ & (1.15) & $(0.36)$ & (1.71) & $(0.29)$ \\
\hline \multirow[t]{2}{*}{1992} & 0.260 & -0.147 & 0.230 & -0.128 & 0.257 \\
\hline & $(0.28)$ & (1.09) & (0.33) & (1.63) & $(0.28)$ \\
\hline \multirow[t]{2}{*}{1993} & $0.583 * *$ & 1.291 & 0.409 & 0.794 & $0.581 * *$ \\
\hline & $(0.26)$ & (1.00) & (0.33) & (1.58) & $(0.26)$ \\
\hline \multirow[t]{2}{*}{1994} & $0.672 * * *$ & -0.0766 & $0.624 *$ & -1.982 & $0.703 * * *$ \\
\hline & $(0.26)$ & (1.08) & $(0.34)$ & (1.64) & $(0.26)$ \\
\hline \multirow[t]{2}{*}{1995} & $0.771 * * *$ & -0.308 & $1.021 * * *$ & -2.187 & $0.774 * * *$ \\
\hline & $(0.29)$ & (1.04) & $(0.34)$ & (1.65) & $(0.29)$ \\
\hline \multirow[t]{2}{*}{1996} & 0.310 & -1.015 & 0.247 & $-3.031 *$ & 0.282 \\
\hline & $(0.32)$ & (1.07) & $(0.41)$ & (1.57) & $(0.32)$ \\
\hline \multirow[t]{2}{*}{1997} & 0.274 & 0.0772 & 0.0243 & -1.768 & 0.275 \\
\hline & $(0.27)$ & (1.28) & $(0.34)$ & (1.66) & $(0.27)$ \\
\hline \multirow[t]{2}{*}{1998} & 0.334 & 0.701 & 0.446 & -1.720 & 0.346 \\
\hline & $(0.28)$ & (1.10) & $(0.34)$ & $(1.76)$ & $(0.28)$ \\
\hline 1999 & 0.501 & 0.281 & $1.554 * *$ & -0.870 & 0.548 \\
\hline & $(0.45)$ & (1.78) & $(0.70)$ & (2.64) & $(0.44)$ \\
\hline dshsli1 & & & & & 0.00102 \\
\hline & & & & & $(0.0041)$ \\
\hline dshsli3 & & & & & 0.00544 \\
\hline & & & & & $(0.0059)$ \\
\hline scst & & & 0.00204 & -0.0237 & -0.000447 \\
\hline & & & $(0.0050)$ & $(0.020)$ & $(0.0040)$ \\
\hline Constant & $0.468 * * *$ & $1.082 * * *$ & $0.495 * * *$ & $1.529 * * *$ & $0.364 * * *$ \\
\hline & $(0.098)$ & $(0.33)$ & $(0.12)$ & $(0.49)$ & $(0.13)$ \\
\hline Observations & 86029 & 10098 & 48158 & 4730 & 84395 \\
\hline R-squared & 0.01 & 0.03 & 0.01 & 0.06 & 0.01 \\
\hline
\end{tabular}

Note: Standard errors are clustered at the district level. All regressions have district and cohort of birth FE 
Table 7: Migration

\begin{tabular}{|c|c|c|}
\hline \multicolumn{3}{|c|}{ Dependent variable: Whether Observed child is male } \\
\hline & 1 & 2 \\
\hline Born in year & All religion Non Migrant & Hindu Non Migrant \\
\hline \multirow[t]{2}{*}{1981} & 0.289 & 0.341 \\
\hline & $(0.29)$ & $(0.34)$ \\
\hline \multirow[t]{2}{*}{1982} & 0.228 & 0.547 \\
\hline & $(0.31)$ & $(0.34)$ \\
\hline \multirow{2}{*}{1983} & 0.0509 & 0.0653 \\
\hline & $(0.36)$ & $(0.40)$ \\
\hline \multirow[t]{2}{*}{1984} & 0.186 & 0.327 \\
\hline & $(0.32)$ & $(0.38)$ \\
\hline \multirow[t]{2}{*}{1985} & 0.373 & 0.436 \\
\hline & $(0.29)$ & $(0.34)$ \\
\hline \multirow[t]{2}{*}{1986} & 0.390 & 0.440 \\
\hline & $(0.25)$ & $(0.29)$ \\
\hline \multirow{2}{*}{1987} & 0.301 & 0.477 \\
\hline & $(0.27)$ & $(0.31)$ \\
\hline \multirow[t]{2}{*}{1988} & $0.455 *$ & $0.686 * *$ \\
\hline & $(0.28)$ & $(0.30)$ \\
\hline \multirow[t]{2}{*}{1989} & $0.705 * *$ & $1.047 * * *$ \\
\hline & $(0.27)$ & $(0.30)$ \\
\hline \multirow[t]{2}{*}{1990} & $0.587 *$ & $0.967 * * *$ \\
\hline & $(0.33)$ & $(0.37)$ \\
\hline \multirow{2}{*}{1991} & 0.186 & 0.378 \\
\hline & $(0.28)$ & $(0.30)$ \\
\hline \multirow[t]{2}{*}{1992} & 0.190 & 0.246 \\
\hline & $(0.26)$ & $(0.30)$ \\
\hline \multirow[t]{2}{*}{1993} & $0.741 * * *$ & $0.675 * *$ \\
\hline & $(0.26)$ & $(0.30)$ \\
\hline \multirow[t]{2}{*}{1994} & $0.549 *$ & $0.746 * *$ \\
\hline & $(0.31)$ & $(0.31)$ \\
\hline \multirow[t]{2}{*}{1995} & 0.421 & 0.599 \\
\hline & $(0.32)$ & $(0.38)$ \\
\hline \multirow[t]{2}{*}{1996} & 0.00519 & 0.132 \\
\hline & $(0.32)$ & $(0.37)$ \\
\hline \multirow[t]{2}{*}{1997} & 0.0285 & 0.207 \\
\hline & $(0.33)$ & $(0.41)$ \\
\hline \multirow[t]{2}{*}{1998} & $0.526^{*}$ & 0.564 \\
\hline & $(0.30)$ & $(0.35)$ \\
\hline \multirow[t]{2}{*}{1999} & 0.263 & 0.597 \\
\hline & $(0.54)$ & $(0.72)$ \\
\hline \multirow[t]{2}{*}{$\mathrm{SC} / \mathrm{ST}$} & -0.00446 & 0.000239 \\
\hline & $(0.0042)$ & $(0.0047)$ \\
\hline \multirow[t]{2}{*}{ Constant } & $0.458 * * *$ & 0.335 \\
\hline & $(0.085)$ & $(0.21)$ \\
\hline Observations & 81223 & 64951 \\
\hline R-squared & 0.01 & 0.01 \\
\hline
\end{tabular}

Note: Standard errors are clustered at the district level. All regressions have district and cohort of birth FE 
Table 8: Relative Mortality of female children in early ages

\begin{tabular}{|c|c|c|}
\hline Dependent variable : & & \\
\hline & 1 & 2 \\
\hline DelTariff*Young & $1.224 *$ & $1.229 *$ \\
\hline & $(0.68)$ & $(0.68)$ \\
\hline Stndrd living (low) & & $-0.0432 *$ \\
\hline & & $(0.024)$ \\
\hline Stndrd living (high) & & -0.0768 \\
\hline & & $(0.059)$ \\
\hline SC/ST (low caste) & -0.0166 & -0.00772 \\
\hline & $(0.029)$ & $(0.031)$ \\
\hline Constant & $0.544 * * *$ & $0.562 * * *$ \\
\hline & $(0.024)$ & $(0.025)$ \\
\hline Observations & 2835 & 2822 \\
\hline R-squared & 0.14 & 0.14 \\
\hline
\end{tabular}

Table 9: Wages

\begin{tabular}{|c|c|c|c|c|}
\hline \multicolumn{5}{|c|}{ Dependent Variable: $\log$ of real wage } \\
\hline & \multicolumn{2}{|c|}{ male } & \multicolumn{2}{|c|}{ female } \\
\hline & Literate & Illiterate & Literate & Illiterate \\
\hline tariff & $\begin{array}{l}-0.0119 * * \\
(0.0057)\end{array}$ & $\begin{array}{l}-0.00190 \\
(0.0057)\end{array}$ & $\begin{array}{l}-0.00160 \\
(0.0077)\end{array}$ & $\begin{array}{l}0.00203 \\
(0.0038)\end{array}$ \\
\hline age & $\begin{array}{l}0.0334 * * * \\
(0.00091)\end{array}$ & $\begin{array}{l}0.00130 * * \\
(0.00060)\end{array}$ & $\begin{array}{l}0.0292 * * * \\
(0.0019)\end{array}$ & $\begin{array}{l}0.00139 * * \\
(0.00061)\end{array}$ \\
\hline scst & $\begin{array}{l}-0.315 * * * \\
(0.021)\end{array}$ & $\begin{array}{l}-0.0615 * * * \\
(0.016)\end{array}$ & $\begin{array}{l}-0.283^{* * *} \\
(0.051)\end{array}$ & $\begin{array}{l}0.0108 \\
(0.019)\end{array}$ \\
\hline Constant & $\begin{array}{l}-0.594 * * * \\
(0.21)\end{array}$ & $\begin{array}{l}-0.533 * * * \\
(0.19)\end{array}$ & $\begin{array}{l}-1.065^{* * * *} \\
(0.28)\end{array}$ & $\begin{array}{l}-1.264 * * * \\
(0.14)\end{array}$ \\
\hline Observations & 54546 & 17725 & 9658 & 17503 \\
\hline R-squared & 0.35 & 0.28 & 0.38 & 0.27 \\
\hline
\end{tabular}

Clustered standard errors in parentheses, Sample contains individuals in the age range $16<$ age $<60$. All regressions include control for religion, year and district fixed effect. *** $\mathrm{p}<0.01, * * \mathrm{p}<0.05, * \mathrm{p}<0.1$ 
Table 10: Dowry

Dependent variable: Real Dowry

\begin{tabular}{lcccc}
\hline & Hindu & Other Religion & $\begin{array}{c}\text { Hindu-Upper } \\
\text { caste }\end{array}$ & $\begin{array}{c}\text { Hindu-Other } \\
\text { castes }\end{array}$ \\
\hline & 1 & 2 & $3 \mathrm{a}$ & $3 \mathrm{~b}$ \\
\hline DelTariff*Post & 210.7 & -89.01 & $727.3 *$ & 191.5 \\
& $(139)$ & $(391)$ & $(424)$ & $(142)$ \\
& & & & \\
Household FE & Yes & Yes & Yes & Yes \\
Year of & & & & \\
Marriage & Yes & Yes & Yes & Yes \\
FE & & & & \\
Constant & $58.23 * * *$ & $140.4 * * *$ & $77.58 * * *$ & $56.66 * * *$ \\
& $(3.45)$ & $(20.8)$ & $(13.4)$ & $(3.64)$ \\
Obs & 3365 & 403 & 235 & 3130 \\
R-squared & 0.80 & 0.90 & 0.94 & 0.79 \\
& & & & \\
\hline
\end{tabular}

Note: Clustered Standard Errors are in parenthesis. Post indicates years of marriage 1992 and up. All regressions control for household and year of marriage fixed effects.

\section{Appendix 1:}

Table A1:

Growth in Employment - percent per annum

\begin{tabular}{|l|l|l|}
\hline & $1980-1989$ & $1988-1997$ \\
\hline Consumer goods & 0.15 & 4.35 \\
\hline Intermediate Goods & -1.38 & 6.54 \\
\hline Capital Goods & 0.75 & 1.40 \\
\hline
\end{tabular}

Source: Pandey, 2004 